\title{
Use of plastic debris as shelter by an unidentified species of hermit crab from the Maldives
}

\author{
João P. Barreiros ${ }^{* \ddagger} \&$ Osmar J. Luiz Jr ${ }^{\dagger}$
}

*Universidade dos Açores, Departamento de Ciências Agrárias and ImarAçores, 970 I-85I Angra do Heroísmo, Portugal. †Departamento de Zoologia, Universidade Estadual de Campinas, I 3083-970 Campinas, SP, Brazil. ${ }^{\ddagger}$ Corresponding author, e-mail: joaopedro@uac.pt

An unidentified species of hermit crab from Maldives was photographed using a plastic box as shelter instead a natural shell. This could be a result of increased pollution and shell collection disrupting the natural processes in coral reefs.

On the 31 January 2008 a recreational diver vacationing in the island of Kuramathi $\left(4^{\circ} 58^{\prime} 08^{\prime \prime} \mathrm{N}\right.$ 74'I'20"E), Maldives, photographed an unknown species of hermit crab (Crustacea: Anomura: Diogenidae) inside an unusual shelter (Figure I). This consists of a plastic box (half of it) widely distributed throughout the world inside chocolate eggs and containing a small toy. The crab's shelter was about $2.5 \mathrm{~cm}$ long and $3.0 \mathrm{~cm}$ in diameter.

Hermit crabs have a wide variety of shelters detailed by several authors (e.g. Turra \& Denadai, 2002; Nakin \& Somers, 2007) and these play highly important roles in their overall ecology (e.g. Biagi et al., 2006).

Unusual shelters are also referred by authors (Garcia et al., 2003) while plastic shelters are even proposed as alternative shelters for hermit crabs with, apparently, important ecological results albeit for terrestrial species (Elizabeth Demaray, unpublished data).

Increased pollution and shell collection together with greater influx of tourism especially in tropical areas such as the case here described may well have a negative effect on the long term survival and stability of hermit crab's survival and population stability. Aspects such as non-stable, light, predator attracting brightly coloured and poor hydrodynamic shelters are important study subjects that do deserve our attention. The question of plastic debris in the oceans is, of course, a matter of much wider relevance already emphasized more than 20 years ago (Wilber, 1987).

We thank Jorge Ávila for the photograph provided.

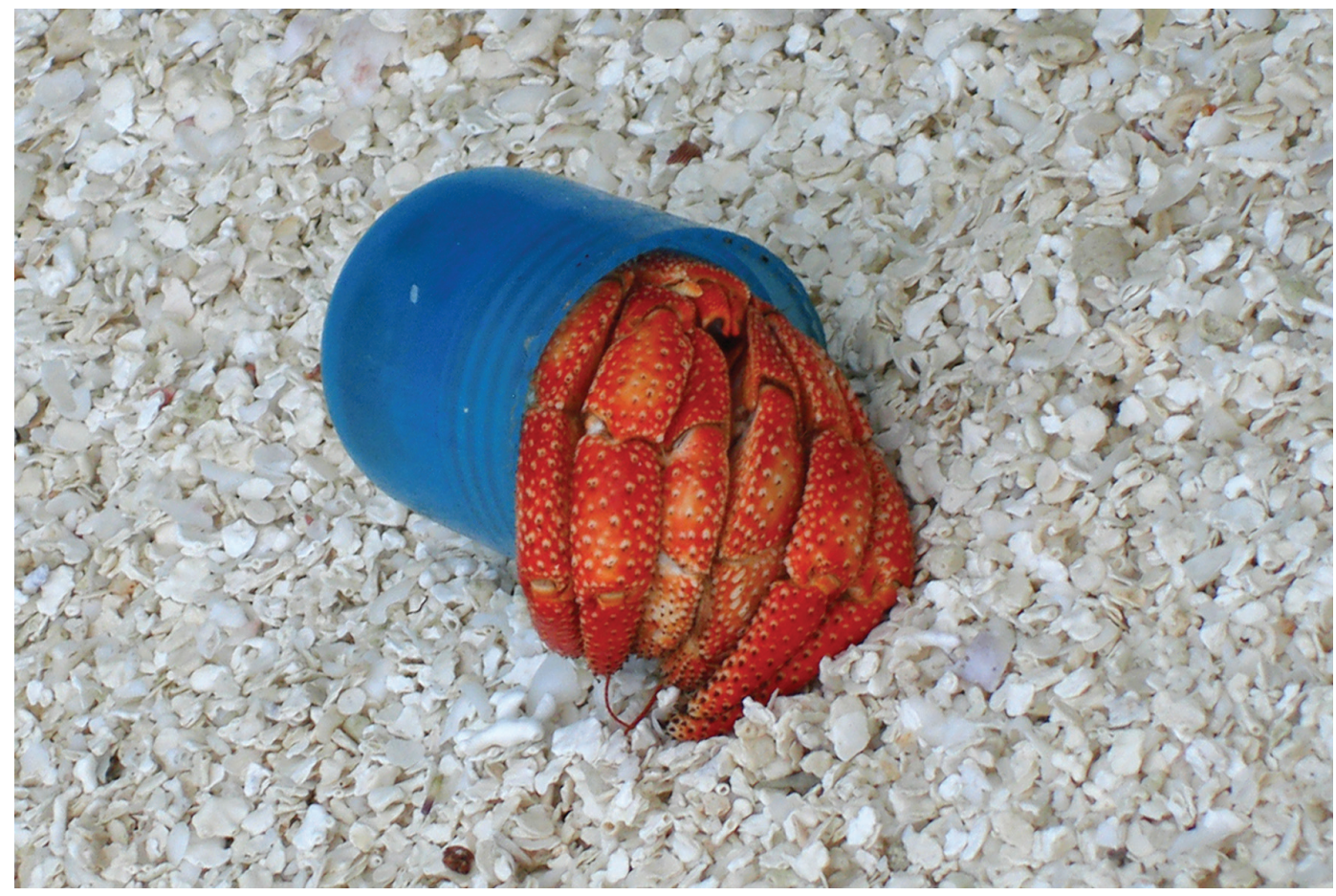

Figure I. Unidentified species of hermit crab inside a plastic box at Kuramahti Island, Maldives Archipelago, Indian Ocean, January 2008. Photograph: Jorge Ávila. 
2 J.P. Barreiros and O.J. Luiz Jr Use of plastic debris as shelter by an unidentified species of hermit crab

\section{REFERENCES}

Biagi, R., Meireles, A.L., Scelzo, M.A. \& Mantelatto, F.L., 2006. Comparative study of shell choice by the southern endemic hermit crab Loxopagurus loxochelis from Brazil and Argentina. Revista Chilena de Historia Natural, 79, $48 \mathrm{I}-487$.

Garcia,R.B.,Meireles,A.L.\& Mantelatto, F.L., 2003. Unusual shelters occupied by Brazilian hermit crabs (Crustacea: Decapoda: Diogenidae). Brazilian Journal of Biology, 63, 72I-722. doi: I0.1590/SI5I9-69842003000400020

Nakin, M.D. \& Somers, M.J., 2007. Shell availability and use by the hermit crab Clibanarius virescens along the eastern Cape Coast, South Africa. Acta Zoologica Academia Scientiarium Hugariae, 53, I49-I55.

Turra, A. \& Denadai, M.R., 2002. Substrate use and selection in sympatric intertidal hermit crab species. Brazilian Journal of Biology, 62, 107-I I2.

Wilber, R.J., 1987. Plastic in the North Atlantic. Oceanus, 30, $6 \mathrm{I}-68$.

Submitted I5 April 2008. Accepted 25 June 2008. 